\title{
Influence of folding wastes on natural environment in Miedzyzdroje
}

\section{Wpływ składowiska odpadów na środowisko naturalne w Międzyzdrojach}

\author{
Piotr Daniszewski, Beata Draszawka - Bołzan \\ Katedra Chemii i Ochrony Środowiska Wodnego \\ Wydział Biologii \\ Uniwersytet Szczeciński \\ ul. Felczaka 3C, 71-412 Szczecin, Poland \\ E-mail address: daniszewski@univ.szczecin.pl
}

\begin{abstract}
Waste is inseparable element of human activity. In Poland, the system of it's management is typically extensive because waste is almost entirely deposited in landfills. Landfilling is the oldest method of waste management, but it is also the least desirable method of its neutralization. During the operation of communal waste landfilling, the waste affects particular elements of environment such as air, soil, water, plants and animals. The aim of conducted researches was to assess the waste disposal sites, which were differentiated by the composition of deposited wastes, on the environment of ground waters and soils properties. They covered the measurements of $\mathrm{pH}$, electrolytic conductivity, total organic carbon (TOC), cyclic aromatic hydrocarbons (CAH) as well as the determination of heavy metals $(\mathrm{Hg})$.
\end{abstract}

\section{Keywords}

waste landfill; communal waste; ground waters; quality; impact on the environment

\section{STRESZCZENIE}

Wytwarzanie odpadów jest nieodłącznym elementem działalności bytowo - gospodarczej człowieka. W Polsce najbardziej rozpowszechniony jest system zarządzania typowo ekstensywny, to dlatego, ponieważ odpady są prawie w całości składowane na składowiskach odpadów. W czasie eksploatacji składowiska odpadów komunalnych oddziałują one na poszczególne elementy środowiska przyrodniczego tj.: powietrze, glebę, wody, rośliny i zwierzęta. Celem badań była ocena oddziaływania składowiska odpadów w Międzyzdrojach na środowisko naturalne. Ocenę stanu wód podziemnych $\mathrm{w}$ rejonie składowiska wykonano na podstawie wyników badań monitoringowych. Badania obejmowały pomiar $\mathrm{pH}$, przewodnictwa elektronicznego właściwego, ogólny węgiel organiczny (OWO), sumę wielopierścieniowych węglowodorów aromatycznych (WWA) oraz zawartość rtęci $(\mathrm{Hg})$.

\section{Stowa kluczowe}

składowisko odpadów, odpady komunalne, wody podziemne, jakość, oddziaływanie na środowisko 


\section{WPROWADZENIE}

Nieodłącznym elementem działalności człowieka są odpady, które powstają w wyniku działalności bytowej i gospodarczej [Biedugnis S. i in. 1992, Kosinkiewicz Z. 2007, Daniszewski P. 2009, Górski M. 2009].

W Polsce przeważającym systemem gospodarki odpadami jest system typowo ekstensywny, gdyż niemal w całości odpady są składowane na składowiskach odpadów [Rosik-Dulewska 2007].

W zagospodarowaniu odpadów powinna funkcjonować zasada - jak najmniejsze kierowanie odpadów na składowisko, a największe do powtórnego wykorzystania [Biedugnis S. i in. 1992, Górski M. 2009].

Aby daną substancję można było uznać za odpad musi spełniać dwa najważniejsze warunki:

1. substancja musi być nieprzydatna w miejscu w jakim powstała, oraz

2. musi być nieprzydatna w danym czasie [Rosik-Dulewska 2007].

Zgodnie z Ustawą z 22 stycznia 2010 roku o zmianie ustawy o odpadach oraz niektórych innych ustaw jako odpady komunalne rozumie się ,odpady powstajace $w$ gospodarstwach domowych, $z$ wyłaczeniem pojazdów wycofanych $z$ eksploatacji, a także odpady nie zawierajace odpadów niebezpiecznych pochodzace od innych wytwórców odpadów, które ze względu na swój charakter lub skład sa podobne do odpadów powstajacych w gospodarstwach domowych".

Dzięki coraz częściej stosowaniu nowych technologii utylizacji odpadów, uzyskać możemy nie tylko odzysk surowców, ale również i energii [Żygadło M. 1998, Grochowicz E. i in. 1999, Mikuła J. 2007].

Składowanie odpadów jest najmniej pożądanym sposobem ich unieszkodliwiania, nie tylko z uwagi na negatywne skutki dla środowiska przyrodniczego, ale również na zdrowie człowieka [Przywarska R. 2005, Mikuła J. 2007, Rosik-Dulewska 2007].

Badania lizymetryczne Oleszkiewicza 1999 wykazały, że przy okresowym wprowadzaniu wód opadowych do składowiska odpadów komunalnych, powodowało to okresowe pojawianie się odcieku, z niewielkim przesunięciem czaszy, co oznacza, że nasycone odpady komunalne nie zatrzymują wody. Woda, która przesącza się przez odpady wymywa $\mathrm{z}$ nich wiele zanieczyszczeń, które mogą stanowić potencjalne zagrożenie dla elementów środowiska przyrodniczego w tym dla zdrowia człowieka [Oleszkiewicz J. 1999, Przywarska R. 2005] .

Jak podaje w swojej pracy Oleszkiewicza 1999 - ,jeżeli roczny opad wynosi 700 mm, a gęstość składowanych odpadów $600 \mathrm{~kg} \mathrm{~m}^{3}$ i zawartość wody $30 \%$, to wówczas odciek wysypiskowy wynosić będzie $4500 \mathrm{~m}^{3}$ ha składowiska. Straty to głównie spływ powierzchniowy oraz ewapotranspiracja [Oleszkiewicz J. 1999]. Skład chemiczny odcieku zależy również od stadium przetworzenia odpadów [Oleszkiewicz J. 1999].

Odcieki ze składowiska odpadów komunalnych w początkowej fazie składowania (tj. do około 5 lat), mają odczyn kwaśny (pH 3,7- 6,4) [Oleszkiewicz J. 1999]. Później wykazują odczyn obojętny lub słaboalkaiczny ( $\mathrm{pH} 7,0-7,6)$, natomiast po upływie 10 lat, wykazują odczyn zasadowy ( $\mathrm{pH} 8,0-8,5)$ [Oleszkiewicz J. 1999]. Odcieki pochodzące z wysypisk komunalnych to także niebezpieczeństwo pod względem higieniczno - sanitarnym [Oleszkiewicz J. 1999, Przywarska R. 2005, Daniszewski P. 2009].

Przez pierwsze 2 - 4 miesiące po złożeniu odpadów, odcieki zawierają duże ilości bakterii, głównie Escherichia coli i Streptococcus [Oleszkiewicz J. 1999, Przywarska R. 2005, Daniszewski P. 2009]. 


\section{CZESŚĆ DOŚWIADCZALNA}

Składowisko komunalne w Międzyzdrojach zlokalizowane zostało w południowo zachodniej części miasta. Składowisko było eksploatowane w latach 1948-2002. Międzyzdroje położone są nad Morzem Bałtyckim, na terenie wyspy Wolin. Klimat wyspy Wolin jest różny od klimatu reszty kraju, ponieważ jest silnie kształtowany obecnością Morza Bałtyckiego. Charakteryzuje go duża wilgotność powietrza, zmienność nasłonecznienia i rozkładu opadów atmosferycznych, siły i kierunku wiatru oraz duże dobowe amplitudy temperatur.

Nieczynne składowisko odpadów komunalnych w Międzyzdojach o pojemności 250 tys. $\mathrm{m}^{3}$ zajmuje powierzchnię 3,0 ha, $\mathrm{z}$ czego samo składowisko odpadów zajmuje powierzchnię 1,0 ha. Składowisko odpadów w Międzyzdrojach nie zostało w fazie projektowania wyposażone $\mathrm{w}$ drenaż ani też nie zostało uszczelnione.

Całość wód powierzchniowych (pochodzących zarówno z opadów atmosferycznych jak i ze spływów powierzchniowych) znajdujących się na terenie lub w bezpośrednim sąsiedztwie składowiska odpadów w Międzyzdrojach odprowadzana jest w kierunku południowym, a następnie wschodnim dzięki sieci rowów odbierających te wody. Dalej wody powierzchniowe prowadzone są do cieku Stary Zdrój, który jest dopływem jeziora Wicko Małe.

Również wody podziemne I poziomu wodonośnego (w którym zainstalowano piezometry) drenowane są przez wody Starego Zdroju i jego dopływów. Spowodowane jest to morfologią terenu. Depresyjny obszar, na którym zlokalizowano składowisko jest hydraulicznie powiązany $\mathrm{z}$ płytko zalegającym poziomem wodonośnym i dzięki temu kierunki spływu wód powierzchniowych oraz odpływu wód podziemnych są zbieżne.

Wody infiltrujące $z$ obszaru składowiska nie stanowią zagrożenia dla lokalnych ujęć wody, ponieważ:

1. w najbliższym otoczeniu składowiska nie ma zlokalizowanych aktualnie eksploatowanych ujęć wody służących jako źródło zaopatrzenia ludności w wodę;

2. wody pochodzące $\mathrm{z}$ rejonu składowiska odprowadzane są siecią rowów melioracyjnych do Starego Zdroju, dalej do jeziora Wicko Małe - nie ma więc możliwości głębszej infiltracji wód pochodzących z rejonu składowiska;

3. teren składowiska odpadów znajduje się poza Głównym Zbiornikiem Wód Podziemnych nr 102.

Celem określenia jakości wód podziemnych na składowisku odpadów komunalnych w Międzyzdrojach zainstalowano:

1. piezometr $\mathrm{P} \mathrm{nr} 1$ - usytuowany od strony dopływu wód podziemnych w rejon składowiska,

2. piezometry P nr 2 oraz P nr 3 - zlokalizowane od strony odpływu wód podziemnych z rejonu składowiska.

Wszystkie piezometry zostały zafiltrowane $\mathrm{w}$ warstwie wodonośnej zbudowanej $\mathrm{z}$ piasków drobnych i średnich, co gwarantuje dopływ wody.

Wody odciekowe pobrano $\mathrm{z}$ zagłębienia terenowego znajdującego się u podnóża skarpy we wschodniej części składowiska.

Wyniki badań laboratoryjnych przedstawionych w niniejszym artykule oparto na metodach referencyjnych dla badanych wskaźników jakości wód powierzchniowych i podziemnych zgodnie z załącznikiem nr 4 do Rozporządzenia Ministra Środowiska z dnia 11 lutego 2004 r. w sprawie klasyfikacji dla prezentowania stanu wód powierzchniowych i podziemnych, sposobu prowadzenia monitoringu oraz sposobu interpretacji wyników i prezentacji tych wód. 
Powyższe rozporządzenie straciło moc z dniem 1 stycznia 2005 r., w związku z czym podana poniżej klasyfikacja ma charakter pomocniczy. Na dzień dzisiejszy nie istnieją obowiązujące akty prawne pozwalające na porównanie otrzymanych wyników badań $\mathrm{z}$ wartościami dopuszczalnymi dla poszczególnych wskaźników jakości wody podziemnej.

Badania prowadzone były w miesiącu kwietniu i październiku 2007 roku. Analizy wykonywano raz w miesiącu (tj. w kwietniu i październiku). Przedstawione w pracy wyniki stanowią średnią z dwóch miesięcy badań.

\section{DYSKUSJA WYNIKÓW}

Wyniki badań wód podziemnych i powierzchniowych wraz z klasyfikacją wartości badanych wskaźników wg kryteriów Rozporządzenia Ministra Środowiska z dnia 11 lutego 2004 r. przedstawiono w tabelach nr 1 i 2.

Tabela 1. Zestawienie wyników badań wód podziemnych wraz z klasyfikacją wartości badanych wskaźników wg kryteriów Rozporządzenia Ministra Środowiska z dnia 11 lutego 2004 r.

\begin{tabular}{|c|c|c|c|c|}
\hline \multirow{2}{*}{$\begin{array}{c}\text { Parametry jakości } \\
\text { wód }\end{array}$} & \multirow[t]{2}{*}{ Jednostka } & \multicolumn{3}{|c|}{$\begin{array}{r}\text { Punkty pomiarowe } \\
\end{array}$} \\
\hline & & $\begin{array}{c}\text { Piezometr nr } 1 \\
\text { dopływ }\end{array}$ & $\begin{array}{c}\text { Piezometr nr } 2 \\
\text { odplyw }\end{array}$ & $\begin{array}{c}\text { Piezometr nr } 3 \\
\text { odpływ }\end{array}$ \\
\hline $\begin{array}{l}\text { Poziom zwierciadła } \\
\text { wód } \\
\text { podziemnych }\end{array}$ & $\begin{array}{l}\text { m p.p.k. } \\
\text { (pomiar } \\
\text { wykonany od } \\
\text { poziomu kryzy) }\end{array}$ & 1,22 & 1,90 & 2,47 \\
\hline pH & - & $6,89(\mathrm{I})$ & $6,92(\mathrm{I})$ & $6,21(\mathrm{I})$ \\
\hline $\begin{array}{l}\text { Przewodnictwo } \\
\text { elektryczne } \\
\text { wlaściwe }\end{array}$ & $\left(\mu \mathrm{S}^{\prime} \mathrm{cm}^{-1}\right)$ & 623 (II) & 2789 (IV) & $3487(\mathrm{~V})$ \\
\hline $\begin{array}{l}\text { Ogólny węgiel } \\
\text { organiczny (OWO) }\end{array}$ & $\mathrm{mg} \mathrm{C} \cdot \mathrm{dm}^{-3}$ & $53,30(\mathrm{~V})$ & $17,65(\mathrm{VI})$ & $48,30(\mathrm{~V})$ \\
\hline Rtęć & $\mathrm{mg} \mathrm{Hg} \mathrm{dm}^{-3}$ & \multicolumn{3}{|c|}{$<0,0005$ (I) } \\
\hline WWA & $\mu \mathrm{g} \cdot \mathrm{dm}^{-3}$ & \multicolumn{3}{|c|}{$<0,01(\mathrm{I})$} \\
\hline
\end{tabular}

Wysoka wartość przewodności elektrolitycznej właściwej nie jest spowodowana negatywnym oddziaływaniem składowiska odpadów na środowisko gruntowo - wodne.

Wysoka wartość tego wskaźnika w wodzie gruntowej, podobnie jak wartości ogólnego węgla organicznego jest skutkiem naturalnego składu fizykochemicznego wody gruntowej w tym rejonie.

Badany obiekt tj. składowisko odpadów w Międzyzdrojach znajduje się na terenie, w którym dominują rowy melioracyjne, zastoiska wody. Dowodzi to obecności płytko zalegającej wody gruntowej, do której w krótkim czasie filtrują wody powierzchniowe pochodzące z opadów atmosferycznych a także spływów powierzchniowych. Wraz z tymi wodami filtrują do przypowierzchniowej warstwy wodonośnej związki organiczne naturalnie występujące w przyrodzie, a posiadające w swoim składzie chemicznym węgiel.

Pozostałe badane wskaźniki były na poziomie I klasy jakości wody. 
Tabela 2. Zestawienie wyników badań wód powierzchniowych wraz z klasyfikacją wartości badanych wskaźników wg kryteriów Rozporządzenia Ministra Środowiska z dnia 11 lutego 2004 r.

\begin{tabular}{|c|c|c|c|}
\hline \multirow{2}{*}{$\begin{array}{c}\text { Parametry jakości } \\
\text { wód }\end{array}$} & \multirow[t]{2}{*}{ Jednostka } & \multicolumn{2}{|c|}{ Punkty pomiarowe } \\
\hline & & $\begin{array}{l}\text { Rów powyżej } \\
\text { składowiska }\end{array}$ & $\begin{array}{l}\text { Rów poniżej } \\
\text { składowiska }\end{array}$ \\
\hline pH & - & $4,96(\mathrm{~V})$ & $6,93(\mathrm{I})$ \\
\hline $\begin{array}{l}\text { Przewodnictwo } \\
\text { elektryczne } \\
\text { wlaściwe }\end{array}$ & $\left(\mu \mathrm{S} \cdot \mathrm{cm}^{-1}\right)$ & 530 (II) & $2104(V)$ \\
\hline $\begin{array}{l}\text { ogólny węgiel } \\
\text { organiczny (OWO) }\end{array}$ & $\mathrm{mg} \mathrm{C} \cdot \mathrm{dm}^{-3}$ & $241,5(\mathrm{~V})$ & $163,5(\mathrm{~V})$ \\
\hline Rtęć & $\mathrm{mg} \mathrm{Hg} \mathrm{dm}^{-3}$ & \multicolumn{2}{|c|}{$<0,0005(\mathrm{I})$} \\
\hline WWA & $\mu \mathrm{g} \cdot \mathrm{dm}^{-3}$ & 0,045 (II) & $0,305(\mathrm{IV})$ \\
\hline
\end{tabular}

W wyniku dokonanej analizy wyników z punktów pomiarowych stwierdzono porównywalne wartości analizowanych parametrów, co świadczy o zbliżonym chemizmie wód powierzchniowych zarówno przed dopływem w rejon składowiska jak i poniżej badanego składowiska odpadów.

Podczas badań zaobserwowano w obu punktach pomiarowych podwyższone wartości ogólnego węgla organicznego - ocena tego wskaźnika wg kryteriów Rozporządzenia Ministra Środowiska z dnia 11 lutego 2004 r. klasyfikuje badana wodę do V klasy jakości. Wysokie stężenia tego wskaźnika związane jest z występowaniem naturalnych związków próchnicznych występujących w warstwie przypowierzchniowej gleby, które w skutek spływu powierzchniowego dostają się do wód powierzchniowych. Podczas prowadzonych badań zaobserwowano wzrost stężenia WWA zarówno powyżej, jak i poniżej badanego wysypiska. W punkcie pomiarowym zlokalizowanym powyżej składowiska odpadów komunalnych w Międzyzdrojach zaobserwowano obniżenie wartości odczynu pH.

\section{Podziękowania}

Autorzy artykułu sktadaja podziękowania Gminie Międzyzdroje ul. Ksiażąt Pomorskich 5 za udostępnienie wyników badań składowiska odpadów komunalnych przy ul. Polnej w Międzyzdroje, które zostały wykorzystane do napisania niniejszego artykułu.

\section{Polskie Normy}

PN/C-04540.03. Badania wartości pH, kwasowości i zasadowości. Oznaczanie kwasowości i zasadowości mineralnej i ogólnej metodą miareczkowania wobec wskaźników.

PN/C-04542. Oznaczanie przewodności elektrolitycznej właściwej.

PN/C-04632.03. Ogólne zasady pobierania próbek do badań fizycznych, chemicznych i biologicznych. Technika pobierania próbek.

PN/C-04632.04. Ogólne zasady pobierania próbek do badań fizycznych, chemicznych i biologicznych. Utrwalanie i przechowywanie próbek.

PN/C-06504. Przygotowanie roztworów buforowych. 


\section{References}

[1] Ambrożewicz P., Zwarty system zagospodarowywania odpadów. Ekonomia i Środowisko, Białystok 1999

[2] Baran S, A. Bojanowicz A., Klasyfikacja odpadów niebezpiecznych. Ochrona Środowiska, Warszawa 2002

[3] Biedugnis S., Cholewiński J., Optymalizacja gospodarka odpadami. PWN, Warszawa 1992

[4] Daniszewski P., Oczyszczalnia ścieków stoczniowych jako źródło emisji bioaerozolii do powietrza atmosferycznego. Gaz, Woda i Technika Sanitarna 4 (2009) 34-36.

[5] Garbulewski K., Dobór i badania gruntowych uszczelnień składowisk odpadów komunalnych. SGGW, Warszawa 2000

[6] Grochowicz E., Korytkowski J., Ochrona przed odpadami. WSiP, Warszawa 1999, s: $10-40$.

[7] Górski M., Przeglad komunalny 1(208) (2009) 54-55.

[8] Kosinkiewicz Z., Przegląd komunalny 3(186) (2007) 48-49.

[9] Łuniewski S., Bezpieczne składowanie odpadów. Ekonomia i środowisko, Białystok 2008

[10] Mikuła J., Przeglad komunalny 4(187) (2007) 40-41.

[11] Oleszkiewicz J., Eksploatacja składowisk odpadów. Wyd. LP s.c. Kraków 1999

[12] Przywarska R., Ochrona Powietrza i Problemy Odpadów 39(39) (2005) 12-17.

[13] Rosik-Dulewska C. Podstawy gospodarki odpadami. PWN, Warszawa 2007

[14] Rozporządzenie Ministra Środowiska z dnia 11 lutego 2004 r. w sprawie klasyfikacji dla prezentowania stanu wód powierzchniowych i podziemnych, sposobu prowadzenia monitoringu oraz sposobu interpretacji wyników i prezentacji tych wód (Dz.U.2004, Nr 32, poz. 284).

[15] Ustawa z 22 stycznia 2010 r. o zmianie ustawy o odpadach oraz niektórych innych ustaw (Dz.U. 2010 nr 28 poz. 145).

[16] Żygadło M. Gospodarka odpadami komunalnymi. Politechnika Świętokrzyska, Kielce 1998. 